\title{
MERAJUT TRADISI DI TENGAH TRANSISI: PENDIDIKAN LINGKUNGAN HIDUP BERBASIS KEARIFAN LOKAL DALAM BUDAYA MAPALUS SUKU MINAHASA
}

\author{
Jekson Berdame \\ Dosen Institut Agama Kristen Negeri (IAKN) Manado \\ jeksonberdame46@gmail.com \\ Charles A. Ray Lombogia \\ Gembala Kerapatan Gereja Protestan Minahasa (KGPM) \\ charlesraylombogia@gmail.com
}

Diterima 6 April 2020

Disetujui 4 Mei 2020

\begin{abstract}
Abstrak
Merajut tradisi dimaknai sebagai tindakan untuk mengembalikan pemahaman masyarakat tentang makna keutamaan sebagai manusia berdasarkan perspektif kearifan lokal atau nilai-nilai kebudayaan yang kian hari kian terkikis oleh globalisasi dan strukturalisme. Masa ini disebut sebagai transisi karena keberdaan manusia yang tidak dapat lepas dari perubahan yang didorong oleh semangat zaman atau ilmu pengetahuan dan teknologi. Penulis memahami bahwa hambatan dan kesulitan dalam menerjermahkan konsep ekologis dalam pengelolaan lingkungan hidup berkelanjutan disebabkan oleh degradasi budaya. Oleh karena itu kapabilitas pendidikan lingkungan hidup dapat tercermin dari sejauh mana kearifan lokal bersama nilai-nilai yang terkandung didalamnya terimplementasi disetiap aspek kehidupan. Metode Penelitian ini menggunakan penelitian kualitatif dengan bentuk deskritif dan dimaksudkan untuk mengidentifikasi peran kearifan lokal atau budaya dalam kerangka pembelajaran lingkungan hidup. Sehingga dapat di deskripsikan bahwa Pendidikan lingkungan hidup berbasis kearifan lokal memiliki pranata nilai-nilai yang terkandung dalam kearifan lokal yakni budaya mapalus suku Minahasa dan keterkaitan erat dengan mentalitas atau kesadaran masyarakat dalam memahami lingkungan hidup dan bahkan lebih jauh dari itu, kearifan lokal juga dapat menjadi barometer dalam memahami konsep lingkungan hidup di setiap tatanan masyarakat khususnya Minahasa.
\end{abstract}

Kata Kunci: Pendidikan Lingkungan Hidup, Kearifan Lokal, Mapalus

\section{PENDAHULUAN}

Filsafat tentang kehidupan yang menyatu dan berdampingan dengan alam, biasa disebut sebagai naturalisme berubah menjadi antroposentrisme. Filsafat tersebut luntur terganti dengan manusia 
sebagai pengendali utama alam, bukan lagi manusia yang menyesuaikan diri dengan alam dan lingkungan. Keadaan tersebut telah berubah, alam dan lingkungan diolah sedemikian rupa untuk mengikuti kehendak dan memenuhi kebutuhan hidup manusia. Berdasarkan hasil observasi dan interview, beberapa masyarakat yang mengeksploitasi alam untuk memenuhi hasrat kemapanan ekonomi dan dengan dalih untuk menyukseskan program pembangunan. Eksploitasi tersebut dapat berupa pengerukan tanah dan pasir pada lahan-lahan subur sehingga mengakibatkan banyak cekungan lebar di berbagai wilayah.

Pada tahun 2010 Universitas Adelaide mempublikasikan hasil penelitian tentang kerusakan lingkungan pada seluruh permukaan bumi. Indonesia menempati urutan keempat setelah Brazil, Amerika Serikat, dan China yang termasuk dalam 10 negara paling berkontribusi dalam perusakan lingkungan. Salah satu indikator yang diukur adalah perubahan alih fungsi lahan menjadi lahan komersil. Krisis lingkungan yang kini mencengkeram bumi adalah akibat konsumsi berlebihan manusia atas sumber daya alam ${ }^{58}$.

58 Bradshaw, Corey, J.A., Giam, Xingli., Sodhi, Navjot S. 2010. Evaluating the Relative Environmental Impact of Countries. Plos One Open Acces- Research Article. (Online), 5 (5): 2010
Keadaan ini bisa menjadikan sebagai rujukan untuk hidup dan bertahan lebih lama sebagai jawaban dalam pola kehidupan yang modern. Kehidupan modern saat ini memiliki kegiatan eksploitasi alam dengan intensitas yang tinggi, merupakan tanda kerusakan lingkungan/alam juga bertambah luas. Kemajuan teknologi tidak menjamin suatu negara/daerah untuk lebih bertanggung jawab terhadap lingkungan. Namun, pola pikir dan gaya hidup masyarakat memiliki peran penting dalam menjaga dan melestarikan lingkungan.

Kearifan lokal merupakan bagian dari masyarakat untuk bertahan hidup sesuai dengan kondisi lingkungan, sesuai dengan kebutuhan, dan kepercayaan yang telah berakar dan sulit untuk dihilangkan, begitu pula Sumarmi dan Amirudin menjelaskan bahwa kearifan lokal merupakan pengetahuan lokal yang digunakan oleh masyarakat untuk bertahan hidup dalam suatu lingkungan yang menyatu dengan sistem kepercayaan, norma, budaya dan diekspresikan dalam tradisi dan mitos yang dianut dalam jangka waktu yang lama. Fungsi kearifan lokal adalah sebagai berikut. Pertama, Sebagai penanda identitas sebuah komunitas. Kedua, sebagai elemen perekat (aspek

(http://journals.plos.org/plosone/article?id=10.1371 /journal.pone.0010440) 
kohesif) lintas warga, lintas agama dan kepercayaan. Ketiga, kearifan lokal memberikan warna kebersamaan bagi sebuah komunitas. Keempat, mengubah pola pikir dan hubungan timbal balik individu dan kelompok dengan meletakkannya di atas common ground/ kebudayaan yang dimiliki. Kelima, mendorong terbangunnya kebersamaan, apresiasi sekaligus sebagai sebuah mekanisme bersama untuk menepis berbagai kemungkinan yang meredusir, bahkan merusak, solidaritas komunal, yang dipercayai berasal dan tumbuh di atas kesadaran bersama, dari sebuah komunitas terintegrasi. ${ }^{59}$

Kearifan lokal merupakan wujud dari perilaku komunitas atau masyarakat tertentu sehingga dapat hidup berdampingan alam/ lingkungan tanpa harus merusaknya. Prawiladilaga menguraikan bahwa kearifan lokal merupakan suatu kegiatan unggulan dalam masayarakat tertentu, keunggulan tersebut tidak selalu berwujud dan kebendaan, sering kali di dalamnya terkandung unsur kepercayaan atau agama, adat istiadat dan budaya atau nilai-nilai lain yang bermanfaat seperti untuk kesehatan,

${ }^{59}$ Sufia, R., Sumarmi, S., \& Amirudin, A. (2016). Kearifan Lokal Dalam Melestarikan Lingkungan Hidup (Studi Kasus Masyarakat Adat Desa Kemiren Kecamatan Glagah Kabupaten Banyuwangi). Jurnal Pendidikan: Teori, Penelitian, dan Pengembangan, 1(4), pp. 726-731. pertanian, pengairan, dan sebagainya. ${ }^{60}$ Merujuk dari perspektif tersebut dapat dijelaskan pula bahwa kearifan lokal yang ada di Minahasa pada umumnya sudah mengakar, bersifat mendasar dan telah menjadi wujud perilaku dari suatu warga masyarakat guna mengelola dan menjaga lingkungan dengan bijaksana demi kedamaian bersama.

\section{METODOLOGI}

Penelitian ini menggunakan penelitian kualitatif pendekatan yang deskriptif dengan mengamati perilaku, persepsi, motivasi, atau tindakan dengan menempatkan informan sebagai subjek penelitian, sehingga mampu didapatkan esensi tentang apa, bagaimana, kapan, dan dimana suatu hal terjadi. ${ }^{61}$ Metode penelitiannya menggunakan teknik studi referensi/kepustakaan untuk memilih informasi penelitian, dan pengumpulan data yang dapat menjadi landasan dasar dan alat utama bagi pelaksanaan penelitian lapangan. ${ }^{62}$ Sedangkan sasaran penelitiannya adalah masyarakat Minahasa. Adapun untuk mengukur validitas penelitian, peneliti menggunakan

60 Prawiradilaga, Wawasan Teknologi Pendidikan. Jakarta: Kencana Prenada Media Group, 2012, p. 26.

61 Sugiyono, Metode Penelitian Kuantitatif,Kualitatif dan R\&D (Bandung; Alfabeta 2008), h. 223-224.

${ }^{62}$ Mardalis, Metode Penelitian, (Jakarta: Bumi Aksara, 2009), h. 28. 
triangulasi sumber dengan membandingkan data hasil pengamatan dan wawancara, keadaan dengan perspektif orang dan hasil wawancara dengan isi dokumen. ${ }^{63}$

\section{KAJIAN TEORI}

\section{Pendidikan Lingkungan Hidup}

Kerusakan lingkungan, alam, bumi dan tata surya merupakan akibat perilaku manusia.Perilaku manusia digerakkan oleh sistem nilai yang diyakini dan dianut oleh seseorang. Dalam kajian psikologi, dimensi manusia memiliki aspek kognitif, afektif dan psikomotorik. Ketiga dimensi itu secara faktual berada pada wilayah jiwa dan raga secara padu.Tak dapat dipilah, dipisah dan dibedakan secara. Pikiran dan perasaan manusia sering kali dapat dilihat dari aktivitas-aktivitasnya dalam kehidupan yang sesungguhnya. Sebab itu, membangun kesadaran harus dimulai dari titik utama yang menggerakan perilaku seseorang, yaitu sisi mentalitas. Mentalitas merupakan bagian urgen dalam tata fisiologi seseorang. Keyakinan, mental dan rasa yang berada pada jalur afektif menjadi penting digerakkan terlebih dahulu. Di samping ia menjadi motor penggerak perilaku transformasi ini tentu membutuhkan jalan

63 Lexy J. Moleong, Metode Penelitian Kualitatif (Bandung: Remaja Rosdakarya, 2005). panjang penyadaran. Dan tentunya juga butuh kemitmen, konsisten serta dayajuang yang tinggi untuk membangun kesadaran masyarakat akan arti penting menjaga lingkungan hidup. Upaya penyadaran dapat dilakukan melalui berbagai cara, di berbagai tempat, dan waktu, tentu harus dilalui secara berkesinambungan. Pendidikan berwawasan lingkungan baik yang dilakukan secara formal, in-nonformal, maupun melalui pendidikaan popular yang mengedepankan local wisdom menjadi tak terelakkan.

Membangun masyarakat sadar lingkungan tidak cukup dilalui dengan jalur pendidikan konvensional. Melalui jalur formal, pendidikan yang berwawasan lingkungan telah dimulai relatif lama. Pada tahun 1986, pendidikan lingkungan hidup dan kependudukan dimasukkan ke dalam pendidikan formal dengan dibentuknya mata pelaj aran, yaitu pendidikan kependudukan dan lingkungan hidup (PKLH). Pada saat bersamaan, departemen pendidikan juga memulai mengintegrasikan PKLH ke dalam semua mata pelajaran.Pada level pendidikan dasar dan menengah (SMP, MTs, SMA, MA), strategi pembelajaran kependudukan dan lingkungan hidup dilakukan secara integratif dan dituangkan dalam sistem kurikulum tahun 1984 dengan 
memasukkan

masalah-masalah

kependudukan dan lingkungan hidup ke dalam hampir semua mata pelajaran. Sejak tahun 1989/1990 hingga saat ini berbagaipelatihan tentang lingkungan hidup telah diperkenalkan oleh Departemen Pendidikan Nasional bagi elemen sekolah: guru dan murid SD, SMP dan SMA termasuk Sekolah Kejuruan. Di tahun 1996 terbentuk Jaringan Pendidikan Lingkungan (JPL) antara LSM-LSM yang berminat dan menaruh perhatian terhadap pendidikan lingkungan. Hingga tahun 2004 tercatat 192 anggota JPL yang bergerak dalam pengembangan dan pelaksanaan pendidikan lingkungan. Selain itu, terbit Memorandum Bersama antara Departemen Pendidikan dan Kebudayaan dengan Kantor Menteri Negara Lingkungan Hidup No. 0142/U/1996 dan No Kep: 89/MENLH/5/1996 tentang Pembinaan dan Pengembangan Pendidikan Lingkungan Hidup, tanggal 21 Mei 1996. ${ }^{64}$ Sejalan dengan itu, Direktorat Jenderal Pendidikan Dasar dan Menengah (Dikdasmen) Depdikbud juga terus mendorong pengembangan dan pemantapan pelaksanaan pendidikan lingkungan hidup di sekolah-sekolah antara lain melalui penataran guru,

64

https://id.wikipedia.org/wiki/Pendidikan_lingkunga n_hidup penggalakkan bulan bakti lingkungan, penyiapan Buku Pedoman Pelaksanaan Pendidikan Kependudukan dan Lingkungan Hidup (PKLH) untuk Guru SD, SLTP, SMU dan SMK, program sekolah asri, dan lain-lain.

Sementara itu, LSM maupun perguruan tinggi dalam mengembangkan pendidikan lingkungan hidup melalui kegiatan seminar, sararasehan, lokakarya, penataran guru, pengembangan sarana pendidikan seperti penyusunan modulmodul integrasi, buku-buku bacaan dan lain-lain. Pada tanggal 5 Juli 2005, Menteri Lingkungan Hidup dan Menteri Pendidikan Nasional mengeluarkan SK bersama nomor: Kep No 07/MenLH/06/2005 No 05/VI/KB/2005 untuk pembinaan dan pengembangan pendidikan lingkungan hidup. Di dalam keputusan bersama ini, sangat ditekankan bahwa pendidikan lingkungan hidup dilakukan secara integrasi dengan mata ajaran yang telah ada. Di sampingitu, persoalan lingkungan hidup juga menjadi perhatian lembaga-lembaga kajian di bawah naungan universitas. Namun demikian, pada kenyataanya hingga kini problem lingkungan hidup juga tidak kunjung usai. Bahkan menunjukan gejala sebaliknya. Perilaku manusia juga tidak berubah setelah proses pendidikan lingkungan dilakukan. Hal ini dapat dilihat 
dari pola konsumsi kebutuhan rumah tangga. Limbah domestik seperti deterjen atau bahan kimia lainnya yang dipakai, pada akhirnya manusia juga yang harus menanggung resikonya. Bahan pembersih yang dipromosikan untuk mempermudah kehidupan manusia pada akhirnya justru merepotkan dan membahayakan kehidupan manusia. Data lapangan menunjukkan bahwa setiap hari produksi sampah yang dilakukan oleh industri, rumah tangga, rumah sakit, peternakan semakin menunjukkan tren meningkat. Padahal pendidikan lingkungan telah diupayakan dengan berbagai cara. Lalu pertanyaannya, seberapa efektifkah dampak pendidikan lingkungan yang selama ini dilakukan melalui jalur pendidikan formal.

Sebab itu, untuk meningkatkan efektifitasnya, dibutuhkan pendidikan lingkungan melalui berbagai jalur dan jenjang yang variatif dan lebih menekankan pada aspek cultural-subtantif. Pendidikan model ini bukan lagi hanya wewanang dinas pendidikan saja, tetapi menjadi tanggungjawab lintas dinas, agama, profesi di segala ruang dan waktu. Di samping itu, pendidikan lingkungan harus partisipatif dan menjadikan konteks lokalitas sebagai laboratoriumnya. Untuk itu, prinsip dasar pendidikan berwawasan lingkungan mestinya berpijak pada standar: 1) mempertimbangkan lingkungan sebagai suatutotalitas. Persoalan lingkungan hidup merupakan persoalan yang bersifat sistemik, kompleks, serta memiliki cakupan yang luas. Oleh sebab itu, materi atau isu yang diangkat dalam penyelenggaraan kegiatan pendidikan lingkungan hidup juga sangat beragam dan kompleks. 2) merupakan suatu proses yang beijalan kontinuitas, secara terus menerus dan sepanjang hidup, dimulai pada jaman pra sekolah, dan berlanjut ke tahap pendidikan formal maupun non formal; 3) pendidikan lingkungan menggunakan pendekatan yang sifatnya interdisipliner. Setiap disiplin ilmu memiliki karakter masingmasing dan ia memiliki andil kontributif dalam mengelola isu-isu lingkungan hidup; 4) meneliti isu lingkungan yang utama dari sudut pandang lokal, nasional, regional dan internasional, sehingga pembelajaran dapat menerima insight mengenai kondisi lingkungan di wilayah geografis yang lain; 5) memberi tekanan pada situasi lingkungan saat ini dan situasi lingkungan yang potensial, dengan memasukkan pertimbangan historisnya; 6) mempromosikan nilai dan pentingnya kerjasama lokal, nasional dan internasional untuk mencegah dan memecahkan masalah-masalah lingkungan; 7) Secara eksplisit 
mempertimbangkan aspek lingkungan dalam rencana pembangunan dan pertumbuhan; 8) mendorong peserta didik untuk berperan dalam merencanakan pengalaman belaj ar mereka, dan memberi kesempatan pada mereka untuk membuat keputusan dan menerima konsekuensi dari keputusan tersebut; 9) menghubungkan kepekaan peserta didik kepada persoalan lingkungan, pengetahuan, keterampilan untuk memecahkan masalah dan klarifikasi nilai pada setiap tahap umur. Padatahap awal, pendidikan lingkungan perlu diberikan tekanan kepada kepekaan terhadap lingkungan tempat mereka hidup; 10) Membantu peserta didik untuk menemukan (discover), gejala-gejala dan penyebab dari masalah lingkungan; 11), Memberi tekanan mengenai kompleksitas masalah lingkungan, sehingga diperlukan kemampuan untuk berpikir secara kritis dengan keterampilan untuk memecahkan masalah. 12) memanfaatkan beraneka ragam situasi pembelajaran (learning environment) dan berbagai pendekatan dalam pembelajaran mengenai dan dari lingkungan dengan tekanan yang kuat pada kegiatan-kegiatan yang sifatnya praktis dan memberikan pengalaman secara langsung (first-hand experience).

\section{Merajut Masa Depan Ekologi Manusia}

Pendidikan lingkungan hidup (environmental education) adalah suatu proses untuk membangun populasi manusia di dunia yang sadar dan peduli terhadap lingkungan secara total dan segala masalah yang berkaitan dengannya, dan masyarakat yang memiliki pengetahuan, keterampilan, sikap dan tingkah laku, motivasi serta komitmen untuk bekerja sama, baik secara individu maupun secara kolektif, untuk dapat memecahkan berbagai masalah lingkungan saat ini, dan mencegah timbulnya masalah baru. ${ }^{65}$

Dengan demikian, pendidikan lingkungan hidup bekerja pada semua wilayah, kognitif, psikomotorik maupun afektif. Pada ranah kognitif, peserta pembelajar secara demokratis dan partisipatis membangun kapasitas pemahaman, melalui diskusi, kajian, dialog interaktif serta riset aksi tentang lingkungan dengan segala problem ekologisnya. Model pendidikan ini kooperatif terhadap segenap kemampuan peserta didikmenujuberpikiryang bebas, kreatif dan inovatif. ${ }^{66}$ Peserta didik secara

\footnotetext{
65 Maghfur Ahmad, Pendidikan Lingkungan Hidup Dan Masa Depan Ekologi Manusia, Jurnal Forum Tarbiyah, Vol 8 No. 1, Juni 2010, h. 67

${ }^{66}$ Musthofa Rembangy. 2008. Pendidikan Transformatif: Pergulatan Kristis Merumuskan
} 
bersama-sama diajak untuk menelaah secara kritis tentang relasi agama, iptek, kapitalisme, globalisasi, industrialisasi, nilai lokalitas dengan problem lingkungan hidup. Kajian ini bisa dilakukan dalam konteks isu-isu lingkungan pada skala global, nasional, regional maupun lokal. Pendekatan yang dilakukan pun harus integratif dan interdisipliner. Hal ini penting, mengingat kajian yang monoapproachs selama ini terbukti gagal dalam mengemban misi pendidikan lingkungan. Pendekatan integrasi dengan bantuan berbagai disiplin juga menjadi keniscayaan mengingat persoalan lingkungan bukan sekedar problem politik, ekonomi, hukum dan sosial an sich, melainkan juga persoalan keyakinan dan budaya.

Pada taksonomi psikomotorik, pendidikan lingkungan difokuskan pada pembentukan sikap dan perilaku peserta. Tentunya pada aspek ini disesuaikan dengan tingkatan perkembangan jiwa dan fisik peserta didik. Aspek motorik pendidikan lingkungan mengaksentuasikan pada bagaimana siswa menerapkan teori dalam perilaku harian. Pada tataran implimentasi, proses pembelajaran dapat dilakukan dengan carayang paling sederhana. Misalnya, Yogyakarta: Teras. h. 100 melibatkan pembelajar membersihkan tempat belajar, memilah dan membuang sampah pada tempatnya, memilih produk yang ramah lingkungan, menanam dan merawat pohon serta menjaga keseimbangan alam. Melalui kegiatan yang sederhana, peserta mulai dikenalkan tentang sikap menj aga dan melestarikan lingkungan. Proses ini perlu dilakukan sejak dini agar pada akhirnya dapat membentuk karaktek di masa yang mendatang.

Pendidikan lingkungan akan lebih efektif jika dilakukan sejak anakmasih kecil. Belajar berwawasan lingkungan akan melahirkan generasi yang memiliki sikap positif terhadap kondisi lingkungan. Cara ini juga diharapkan akan melahirkan pemimpinyang memiliki sensitifitas ekologis yang tinggi. Praktik illegal logging, penjarahan sumberdaya alam, pengerukan bukit, penggundulan hutan, maraknya pencemaran yang dilakukan para pelaku bisnis membuktikan pendidikan lingkungan belum dilakukan secara efektif dan juga bisajadi karena orientasi yang salah sasaran.

Mengingat pendidikan lingkungan terkait dengan persoalan nyata, maka semestinya strategi pembejaran yang dilakukan juga menjadi bagian dari penyelesaian problem lingkungan hidup. Pada wilayah psikomotorik inilah, 
pendidikan lingkungan hidup sudah seharusnya dapat mempermudah pencapaian keterampilan tingkat tinggi (higher order skill) seperti: berpikir kritis, kreatif, integratif dan mampu memecahkan masalah lingkungan setempat.

Beberapa keterampilan yang diperlukan dalam pendidikan untuk memecahkan masalah lingkungan adalah 1). berkomunikasi: mendengarkan, berbicara di depan umum, menulis secara persuasif dan desain grafis. Komunikasi baik melalui lisan, tulisan atau media visual lainnya dalam rangka kampanye pentingnya menj aga lingkungan akan mempengaruhi sikap dan perilaku ekologis seseorang. Melalui media kampanye ini, perilaku positif akan memiliki daya dorong untuk mempengaruhi opinipublic yang lebih ekspansif. Di sisi lain, kampanye juga menjadi media pengingat bagi peserta didik dan orang lain agar konsisten akan peijuangan konservasi lingkungan. 2). investigasi (investigation)-, merancang survei, studi pustaka, melakukan wawancara, menganalisa data. Keterampilan ini masuk pada wilayah psikomotirik peserta didik. Melalui kerja merancang, melakukan dan melaporkan problem lingkungan, peserta didik diaj arkan agar memiliki pemahaman dan perilaku yang lebih baik tentang masalah lingkungan. 3). keterampilan bekerja dalam kelompok (groupprocess): kepemimpinan, pengambilan keputusan dan keijasama. Pendidikan lingkungan hidup mestinya juga dapat membangun skill bagi peserta untuk bekeija secara kolektif dan berjuang bersama memperbaiki perilaku pemimpin, pejabat, pelaku modal, serta masyarakat luas dalam mengelola sumber daya alam.

Sedangkan aspek afektif, pendidikan lingkungan berangkat dari keyakinan, nilai dan komitmen yang diperlukan untuk membangun masyarakat yang berkelanjutan (sustainable). Pencapaian tujuan afektif ini biasanya sukar dilakukan. Namun demikian, tentu dapat dilihat dari perilaku nyata yang bersangkutan. Kondisi afeksi seseorang dalam pandangan psikolog sering dijelaskan melalui logika empiris seseorang. Oleh karena itu, dalam pembelajaran segi afeksi diperlukan muatan metodologis yang memungkinkan berlangsungnya dialog interaksi, klarifikasi dan internalisasi nilai-nilai ekologis.

\section{Kearifan Lokal Sebagai Barometer}

\section{Pendidikan Lingkungan Hidup}

Kearifan lokal (local wisdom) dalam kamus Indonesia terdiri dari dua kata: kearifan (wisdom) dan lokal (local). Dalam Kamus Inggris Indonesia John M. Echols dan Hassan Syadily, lokal berarti setempat, sedangkan wisdom (kearifan) 
sama dengan kebijaksanaan. Secara umum maka local wisdom (kearifan setempat) dapat dipahami sebagai gagasan-gagasan setempat atau lokal yang bersifat bijaksana, penuh kearifan, bernilai baik, yang tertanam dan diikuti oleh anggota masyarakatnya. Dalam disiplin antropologi dikenal istilah local genius. Gobyah mengatakan bahwa kearifan lokal atau local genius adalah kebenaran yang telah mentradisi atau ajeg dalam suatu daerah. Kerifan lokal merupakan perpaduan antara nilai-nilai suci firman Tuhan dan berbagai nilai yang ada. Kearifan lokal terbentuk sebagai keunggulan budaya masyarakat setempat maupun kondisi geografis dalam arti luas. Kearifan lokal merupakan produk budaya masa lalu yang patut secara terus- menerus dijadikan pegangan hidup.Meskipun bernilai lokal tetapi nilai yang terkandung didalamnya dianggap sangat universal.

Menurut Caroline Nyamai-Kisia kearifan lokal adalah sumber pengetahuan yang diselenggarakan secara dinamis, berkembang dan diteruskan oleh populasi tertentu yang terintegrasi dengan pemahaman mereka terhadap alam dan budaya sekitarnya. Kearifan lokal adalah dasar untuk pengambilan kebijakkan pada level lokal di bidang kesehatan, pertanian, pendidikan, pengelolaan sumber daya alam dan kegiatan masyarakat pedesaan. ${ }^{67}$ Dalam kearifan lokal, terkandung pula kearifan budaya lokal. Kearifan budaya lokal sendiri adalah pengetahuan lokal yang sudah sedemikian menyatu dengan sistem kepercayaan, norma, dan budaya serta diekspresikan dalamtradisi dan mitos yang dianut dalam jangka waktu yang lama. ${ }^{68}$ Dengan demikian kerifan lokal merupakan suatu gagasan konseptual yang hidup dalam masyarakat, tumbuh dan berkembang secara terus-menerus dalam kesadaran masyarakat, berfungsi dalam mengatur kehidupan masyarakat dari yang sifatnya berkaitan dengan kehidupan yang sakral sampai yang profan.

Namun sangat disayangkan jika menilik semangat kolektivitas atau gotong royong sebagai perwujudan kearifan lokal tampaknya belum terimplementasikan dalam perekonomian nasional yang makin didominasi oleh asing dan perusahaan multinasional dengan semangat neoliberalisme dan neokapitalisme. Ketergantungan ekonomi pada asing menyebabkan kita dengan mudah didikte oleh kekuatan ekonomi dan politik asing.

${ }^{67}$ Caroline Nyamai-Kisia, 2010, Kearifan Lokal, diakses melalui https://kelasips.com/contohkearifan-lokal/

68 Sartini. (2004). Menggali Kearifan Lokal Nusantara Sebuah Kajian Filsafati. Jurnal Filsafat Jilid 37, Nomor 2, h. 111 
PEMBAHASAN

\section{Mapalus (Kearifan lokal Minahasa)}

Minahasa merupakan salah satu kabupaten di provinsi Sulawesi Utara.Minahasa dikenal dengan kebudayaannya yang banyak, dimulai dari kebudayaan dalam bidang kesenian baik tarian, rumah adat dan kegiatan sosial yang sering dilakukan oleh masyarakat Minahasa. J. Turang mengemukakan: Pandangan masyarakat Minahasa, bahwa hakekat manusia adalah "makhluk kerja bersama berke-Tuhan-an". Manusia hidup untuk be- kerja bersama berke-Tuhan-an, bukan bekerja sendiri tetapi bekerja bersama (Working Togetherness), bukan bekerja bersama mengandalkan atau untuk kepentingan hidup material tetapi bekerja bersama atas amanat "Opo Empung", "Opo Rengan rengan", "Opo Wailan", atau nama lainnya, dalam bahasa daerah Minahasa (Tuhan Yang Maha Esa). Oleh karenanya setiap memulai dan menyelesaikan/memperoleh hasil pekerjaan harus dilakukan upacara sakral dipimpin oleh Walian (pemimpin keagamaan dalam Agama Tua). Sebelum upacara dilaksanakan harus mendengar suara burung manguni atau melihat tandatanda alam lainnya atau cara lainnya, sebagai petunjuk Tuhan Yang Maha Esa kepada masyarakat melalui Walian atau Pemimpin masyarakat (Tonaas). ${ }^{69}$

Ada sejumlah nilai dasar dari kearifan lokal yang di junjung tinggi dan menjadi kaedah-kaedah hidup manusia/masyarakat Minahasa :

- Nilai religius : kesucian, kesalehan, kejujuran, keadilan, kebenaran. Personifikasi nilai-nilai religius ditampilkan oleh Walian (Pemimpin Agama Tua) yang menjadi penghubung (Mediator) Opo Empung dengan manusia/masyarakat.

- Nilai lingkungan (ekologis): Eluren Eng Kayobaan, yang berarti jaga dan pelihara bumi.

- Nilai Estetika (keindahan) : nilai keindahan ini ditampilkan dalam berbagai bentuk dan karya seni (seni suara, seni musik, sei tari, dsb) dalam berbagai kegiatan/media, seperti "sambil bekerja menyanyi", dalam setiap upacara sakral (Rumages) terdapat unsur seni tari/musik/suara, ukiran pada tiang rumah adat, ukiran pada wa- ruga, dan sebagainya. Oleh karenanya seorang seniman sebagai personifikasi nilai-nilai estetika, sangat dihormati dalam masyarakat tradisional Minahasa.

- Nilai kebenaran hakiki

69 Prof. DR. J. Turang, dkk. November 1997. Profil Kebudayaan Minahasa. Majelis Kebudayaan Minahasa. Tomohon 
(kebijaksanaan): diakui sebagai Nuwu $T u^{\prime} a h$ (Amanat Luhur). Personifikasi "Nuwu Tu'ah" ialah "Tumutuzuk" (Guru) sebagai orang bijaksana. Simbol legen- daris orang bijaksana antara lain yang bernama Karema, Lumimuut dan Toar.

- Nilai etika: yang menjadi kaedahkaedah moral kehidupan bersama, kehidupan bersama sekampung (Kawanua), perkawinan suami-istri yang monogami (hanya ada satu suami dan hanya satu istri). Personifikasi nilai etika ialah "Kaawu" (Suami-Istri). Oleh karenanya "Orang Tua", si Ina (Ibu)wo si Amak (Ayah) sangat dihormati dalam kehidupan keluarga/masyarakat.

- Nilai kebenaran akali : diakui kebenaran berdasarakan pengalaman dari waktu ke waktu yang menjadi petunjuk/nasehat dalam kehi- dupan misalnya "menebang kayu" pada waktu yang tepat (Oras) supaya tidak cepat rusak, ber- cocok tanam pada bulan yang tepat supaya tidak ada hama, dan sebagainya.

- Nilai demokratis : nilai demokratis ditampilkan oleh Tonaas dalam kepemimpinan masyarkat yang mendasarkan/menghargai

suara/aspirasi rakyat, menjunjung tinggi Musyawarah dan Mu- pakat
Adat. Dan pada pihak lain, Tonaas sebagai orang yang diangkat/diakui sebagai pemimpin karena karya gemilang dan unggul dalam banyak hal dalam masyarakat yang patut diteladani dan menjadi panutan masyarakat.

Nilai kebersamaan : nilai kebersamaan ditampilkan "Hidup Bersama dan Maju Bersama" (Gotong Royong Khas Minahasa), rasa persahabatan dan ketamah-tamahan yang tinngi, rasa sepenanggungan dalam suka (mapalus menyiapkan makanan dan minuman pesta pernikahan, memberikan dana bantuan pernikahan, dsb), sepenanggungan dalam duka (mapalus "mekan" memberikan dana duka, dsb), mapalus membangun rumah, mapalus buka/ mengolah kebun, dan sebagainya.

- Nilai kekeluargaan : nilai kekeluargaan ditampilkan dalam rukun-rukun keluarga, rukun sedaerah asal (Rukun Kawanua), rukun kam- pung, dan sebagainya.Oleh karenannya personifikasi masyarakat Minahasa ialah "sangat menghormati orang tua dan orang yang ditua- kan" (senior).

Nilai kerja keras bersama : nilai kerja keras ber- sama menjadi kewajiban setiap warga masyarakat. Tempo dulu seorang anggota kerja mapalus yang 
malas/terlambat akan dikenai sanksi dipukul atau sanksi lainnya oleh pemim-pin kelompok.

Dengan kerangka nilai di atas, maka yang dapat dikatakan bahwa kerarifan lokal Minahasa telah menyentuh taksonomi pendidikan lingkungan hidup. Entah dari segi kognitif, psikomotorik maupun afektif. Hal itu dapat dilihat dari perspektif pengolahan lingkungan hidup berkelanjutan dengan menekankan tiga aspek utama.Yaitu; Aspek lingkungan (ekosistem). Konsep Eluren Eng Kayobaan, yang berarti jaga dan pelihara bumi. $^{70}$ Eluren Eng Kayobaan, mengandung kerangka nilai, norma, etika sebagai acuan kultural dan kearifan lokal terhadap cara pandang, sikap dan perilaku masyarakat adat Minahasa dalam rangka "membangun relasi dan komunikasi dengan lingkungan sekitar." Eluren Eng Kayobaan, mengandung mandat budaya dan kearifan lokal untuk membangun diri dan masa depan bersama dengan senantiasa menjaga dan memelihara alam. Mapalus sebagai filosofi agraris masyarakat adat Minahasa, merupakan wujud implementasi kerangka makna

70 Pieter George Manoppo, MENGELOLA EKOSISTEM, EKONOMI DAN SUMBER DAYA MANUSIAKOMUNITAS LOKAL BERBASIS BUDAYA DAN KEARIFAN LOKAL MINAHASA (TRIANGEL PA'DIOR), Konferensi Nasional Riset Manajemen VIII, Denpasar, 10-12 Oktober 2014, p. 22
Eluren Eng Kayobaan. Pandangan kultural-ekologis Eluren Eng Kayobaan nampak pula melalui kerjasama, berbagi, dan saling mendukung di antara komunitas masyarakat adat Minahasa dalam menata dan mengelola pekerjaan sebagai petani \& mengolah hutan. Aspek ekonomi. Konsep kultural dalam mapalus merupakan formula filosofi masyarakat adat dan petanian Minahasa dalam mengimplementasikan kerangka makna dari Eluren Eng Kayobaan. Pandangan kultural-ekologis Eluren Eng Kayobaan nampak pula melalui kerjasama, berbagi, dan saling mendukung di antara komunitas masyarakat adat Minahasa dalam menata dan mengelola pekerjaan sebagai petani. Mapalus merupakan fondasi kulturalekonomi petani Minahasa dalam konteks agraris-kontinenal dalam membangun modal sosialnya: saling percaya, relasi sosial, solidaritas, integrasi, sinergisitas, kohesi sosial, jaringan sosial dsb. Mapalus adalah hakikat dasar dan aktivitas kehidupan orang Minahasa (Manado) yang terpanggil dengan ketulusan hati nurani yang mendasar dan mendalam (touching hearts) dengan penuh kesadaran dan tanggung jawab menjadikan manusia dan kelompoknya (teaching mind) untuk saling menghidupkan dan menyejahterakan setiap orang dan kelompok dalam komunitasnya (transforming life). Menurut buku, The 
Mapalus Way, mapalus sebagai sebuah sistem kerja yang memiliki nilai- nilai etos seperti, etos resiprokal, etos partisipatif, solidaritas, responsibilitas, gotong royong, good leadership, disiplin, transparansi, kesetaraan, dan trust Prinsip ekonomi "Tamber" merujuk pada suatu kegiatan untuk memberikan sesuatu kepada orang lain, atau warga sewanua (sekampung) secara sukarela dan cuma-cuma, tanpa menghitung-hitung atau mengharapkan balas jasa. Prinsip ekonomi Tamber berasaskan kekeluargaan. Dari segi motivasi adat, prinsip ini mengandung suatu makna perekat kultural (cagar budaya) yang mengungkapkan juga kepedulian sosial, bahkan indikator keakraban sosial. Aspek manajemen sumber daya manusia, sitou timou tomou tou.Yang berarti "manusia baru dapat disebut sebagai manusia, jika sudah dapat memanusiakan manusia."). Agar mata rantai kultural-ekologis- ekonomis itu senantiasa kokoh, maka mata rantai Si Tou Timou Tumou Tou memperoleh tempat dan fungsinya. Bukan $\mathrm{Si}$ Tou Timou Tumengko Tou, yakni "manusia hidup untuk menghancurkan manusia lain." Manusia dan masyarakat adat Minahasa tidak hidup untuk dirinya sendiri, tidak memangsa saudara dan keluarganya sendiri, bukan untuk keluarganya sendiri, bukan untuk dusun-dusunnya sendiri, tetapi untuk seluruh alam, seluruh ulayat, seluruh manusia, dan seluruh masyarakat adat Minahasa. Bukan untuk sejarah masa lalu saja, bukan juga hanya untuk hari ini, tetapi untuk sejarah gerenasi ke generasi masyarakat adat Minahasa secara berkelanjutan.

\section{KESIMPULAN}

Dari pembahasan yang telah dipaparkan, maka dapat di deskripsikan bahwa pranata nilai-nilai yang terkandung dalam kearifan lokal (budaya mapalus suku Minahasa) memiliki keterkaitan yang erat dengan mentalitas atau kesadaran masyarakat dalam memahami lingkungan hidup dan bahkan lebih jauh dari itu, kearifan lokal juga dapat menjadi barometer dalam memahami konsep lingkungan hidup di setiap tatanan masyarakat (khususnya Minahasa). Dengan demikian melalui tulisan ini, kiranya kita dapat memahami bahwa kearifan lokal bukan semata-mata sarana mengenal sejarah tapi juga dapat menjadi media untuk kita mempersiapkan generasi yang akan datang. Suatu generasi yang berperadan indonesia (cultural) yang bernalar ekologis (universal) atau dengan kata lain, menghadirkan suatu tatanan sosial yang berpikiran global dan berindak lokal.

Melalui sajak di bawah ini, saya mengajak kita semua untuk senantiasa 
menyadari betapa pentingnya arti "kesadaran” dalam memahami lingkungan.

\section{DAFTAR PUSTAKA}

Bradshaw, Corey, J.A., Giam, Xingli., Sodhi, Navjot S. 2010. Evaluating the Relative Environmental Impact of Countries. Plos One Open AccesResearch Article. (Online), 5 (5): 2010

Keraf, S. 2010. Etika Lingkungan Hidup. Jakarta: PT. Kompas Media Nusantara

Sufia, R., Sumarmi, S., \& Amirudin, A. (2016). Kearifan Lokal Dalam Melestarikan Lingkungan Hidup (Studi Kasus Masyarakat Adat Desa Kemiren Kecamatan Glagah Kabupaten Banyuwangi). Jurnal Pendidikan: Teori, Penelitian, dan Pengembangan.

Prawiradilaga. 2012. Wawasan Teknologi Pendidikan. Jakarta: Kencana Prenada Media Group

Maghfur Ahmad, Pendidikan Lingkungan Hidup Dan Masa Depan Ekologi Manusia, Jurnal Forum Tarbiyah, Vol 8 No. 1, Juni 2010, h. 67

Rembangy, Musthofa. 2008. Pendidikan Transformatif: Pergulatan Kristis Merumuskan Pendidikan di Tengah Pusaran Arus Globalisasi, Yogyakarta: Teras. h. 100

Caroline Nyamai-Kisia, 2010, Kearifan Lokal, diakses melalui https://kelasips.com/contoh-kearifanlokal/
Sartini. (2004). Menggali Kearifan Lokal Nusantara Sebuah Kajian Filsafati. Jurnal Filsafat Jilid 37, Nomor 2 , h. 111.

Prof. DR. J. Turang, dkk. November 1997. Profil Kebudayaan Minahasa. Majelis Kebudayaan Minahasa. Tomohon

Gobyah, Pengenalan Keraifan Lokal Indonesia. 2003 Rineka Cipta: Jakarta

Sudjoko, M.S., Perkembangan dan Konsep Dasar Pendidikan Lingkungan Hidup. 2012.

Pieter George Manoppo, Mengelola Ekosistem, Ekonomi Dan Sumber Daya Manusiakomunitas Lokal Berbasis Budaya Dan Kearifan Lokal Minahasa (Triangel Pa'dior), Konferensi Nasional Riset Manajemen VIII, Denpasar, 10-12 Oktober 2014 